\title{
See: How Indonesian Student Writers Use Directives in Academic Texts
}

\section{Cita Nuary Ishak ${ }^{1}$ iD Yazid Basthomi ${ }^{\circledR}$ Utami Widiati ${ }^{3}$ Maria Hidayati ${ }^{4}$ Nurenzia Yannuar ${ }^{5}$}

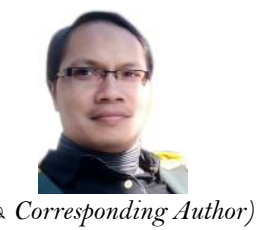

'Instructor, Language Center, Universitas Muhammadiyah Malang, Indonesia. Email:nuarycita@gmail.com

'Professor of Applied Linguistics, Department of English, Faculty of Letters, Universitas Negeri Malang, Indonesia.

sEmail:ybasthomi@um.acid

${ }^{3}$ Professor of TEFL, Department of English, Faculty of Letters, Universitas Negeri Malang, Indonesia.

'Email:utami.widiatifs@um.ac.id

${ }_{4,5}^{4,}$ Lecturer, Department of English, Faculty of Letters, Universitas Negeri Malang, Indonesia.

-Email:maria.hidayatifs@um.ac.id

sEmail:nurensia.yannuar.fs@um.ac.id

\section{Abstract}

This study investigates the roles and functions of directives in academic texts mainly produced by Indonesian college students. Sixty-two (62) imperatives, 11 "it is + Adjective + to"-clauses, and 7 modals of obligation are searched for in academic texts taken from the Corpus of State University of Malang Indonesian Learners English (C-SMILE) and the Corpus of Indonesian Texts in Academia (CINTA). As a point of comparison, we use the Corpus of Contemporary American English (COCA). We found that the corpora are similar regarding the high frequency of occurrences of the imperative see, among other directives. However, the corpora differ with regards to the functions of the imperative see. Whilst see in COCA plays an important role in directing readers to both internal and external sources, see in C-SMILE and CINTA is used exclusively to refer to internal resources. This suggests a lack of access on the part of Indonesian undergraduates' to necessary reading materials. In addition, other directives, such as cognitive imperatives, are rarely used in the Indonesian corpora. The low frequency of cognitive imperatives indicates that the practice of inviting readers to develop their mental process of understanding has not been well established in Indonesian academic culture. These findings suggest the need to introduce to Indonesian student writers, various ways of engaging readers into texts.

Keywords: Directives, Imperatives, Reader engagement, C-SMILE, CINTA, COCA.

Citation | Cita Nuary Ishak; Yazid Basthomi; Utami Widiati; Maria Hidayati; Nurenzia Yannuar (2020). See: How Indonesian Student Writers Use Directives in Academic Texts. Journal of Education and e-Learning Research, 8(1): 65-76.

\section{History:}

Received: 8 January 2020

Revised: 3 December 2020

Accepted: 30 December 2020

Published: 25 January 2021

Licensed: This work is licensed under a Creative Commons

Attribution 3.0 License $(\mathrm{cc}) \mathbf{E}$

Publisher: Asian Online Journal Publishing Group
Acknowledgement: All authors contributed to the conception and design of the study.

Funding: This work was supported by a grant provided by Direktorat Riset dan Pengabdian Masyarakat, Kemendikbud, Republik Indonesia, 2020.

Competing Interests: The authors declare that they have no conflict of interests.

Transparency: The authors confirm that the manuscript is an honest, accurate, and transparent account of the study was reported; that no vital features of the study have been omitted; and that any discrepancies from the study as planned have been explained.

Ethical: This study follows all ethical practices during writing.

\section{Contents}

1. Introduction

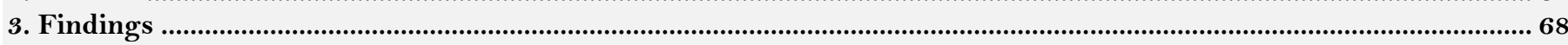

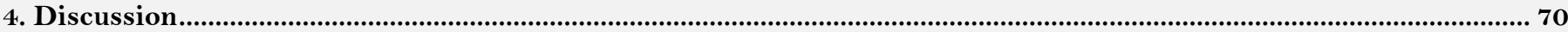

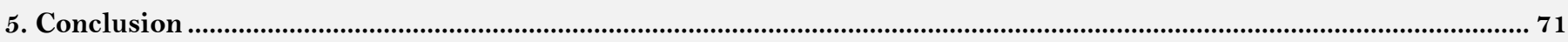

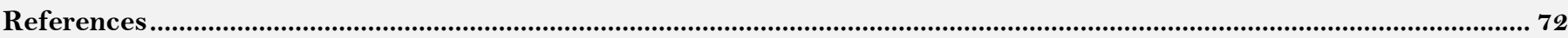




\section{Contribution of this paper to the literature}

This study is a contribution to the relevant literature, as few studies have previously attempted to analyze engagement in undergraduate theses written by Indonesian students. As persuasion is a key factor to academic writing, it is important to make learners aware of different kinds of directives. From a pedagogical perspective, we suggest that universities should provide more reading materials to support learners' academic writing and that language teachers raise awareness of the need to use engagement markers in academic texts and assist learners to develop a convincing and engaging authorial voice.

\section{Introduction}

As per Toolan (2007), a text not only seeks to be accepted by readers but also aims at earning their trust, for "[a] text is an act of trust, a process of entrusting, whether we like it or not." This also holds in the case of academic texts. Academic writing is a "social construct" (Swales et al., 1998) in which writers communicate ideas and convey arguments to their readers. In a corresponding vein, Hyland (2002b) argues that academic discourse is a form of social action that is designed to advance social purposes. For this reason, writers' abilities to create positive interactions and build strong relationships with their readers are central to constructing a persuasive argument, by means of a reader relationship that can draw them into agreement.

These perspectives demonstrate that the flow of arguments in an academic text is determined by the writer's awareness of both the presence and the needs of the target audience. They further highlight that, in order to persuade readers of the writer's viewpoint, the importance of the writer-reader relationship in academic texts cannot be underestimated. And because readers have the freedom to either trust a text or not, writers must be prepared to confront the possible convictions, expectations, and objections of their readers in order to secure their agreement. To achieve this, authors inevitably need to deploy some linguistic devices that allow them to involve the reader in the argument, as well as persuade them into agreement with the author.

Hyland (2005) identifies the key resources required to build successful academic interaction and divides them into two classes "stance" and "engagement." Stance concerns the methods by which writers project themselves and express their attitudes toward certain information in the text; engagement describes the features that are focused on reader interaction. Stance and engagement are thus 'two sides of the same coin' (Hyland, 2008) that work together to establish an intimate interaction between writers and readers. Directives are one of the engagement markers, and are the focus of the present article because of their dual nature. Whereas Brown and Levinson (1987) categorize directives as bald-on-record face-threatening acts that can damage an interaction, Hyland (2002b) believes that directives have a positive role to play in academic texts through the creation of dialogic interaction between writers and their readers.

These two seemingly opposing functions of directives have caused them to be neglected in the literature (see Hyland, 2002b; Swales et al., 1998). The present article responds to this gap by exploring the patterns and functions of directives in academic texts produced by American novice writers and advanced Indonesian EFL learners. This research compares empirical data from corpora of native speakers and non-native speakers of English in an attempt to provide possible explanations for their different practices of engaging readers, as well as to explore non-native behavior in academic writing.

Previous studies on reader engagement in academic writing have been carried out by Swales et al. (1998) and Hyland (2002b). Swales et al. (1998) examined the role of imperatives in research articles from ten disciplines and concluded that the distribution of imperatives differs across disciplines, as well as across article sections. Similarly, Hyland (2002b) also reported that directives, including imperatives, vary across text types and disciplines. Inspired by these studies, the current study constitutes an attempt to increase the empirical data around the issue. This article compares and contrasts academic texts from three corpora, identifies the patterns and functions of the directives, and conducts an interpretive analysis on the different practices of employing directives.

Drawing on Hyland's (2005) model of metadiscourse, Khoshsima, Talati-Baghsiahi, Zare-Behtash, and SafaieQalati (2018) investigated interactional metadiscourse markers in writings produced by Iranian graduate students and established members of academic communities. They found that in contrast to the experienced authors, the graduate students tended to avoid using directives in their writing, which might be attributed to the students' cultural preferences for maintaining politeness. More recently, Alkhathlan (2019) compared the interactive and interactional markers defined by Hyland (2005) in research articles written by Saudi EFL college students. The study revealed that the students prioritized organizing the text over engaging the readers in the text. He argued that this might be caused by the lack of explicit instruction on how to employ such markers and their importance in academic persuasion in a written context.

In contrast to the studies above, the focus of the present article is on how non-native speakers of English, in this case advanced Indonesian EFL students, acknowledge and involve their readers into their texts through the use of directives. Previous research into the writer-reader relationship in academic texts produced by advanced Indonesian EFL students (see e.g. Guswenda, 2013; Wijayanti, 2013)) has focused on how writers project themselves rather than on the writers' perception of who their readers are and how they respond to them. In fact, Hyland (2005) acknowledged that "the ways writers bring readers into the discourse to anticipate their possible objections and engage them in appropriate ways have been relatively neglected in the literature." Consequently, little is known about these students' strategies to make their readers feel "welcome" in the texts. Adel and Römer (2012) also noted that studies on unpublished but advanced student writing are quite rare, and as a result little is known about the types, rhetoric, and styles of student academic writing.

Taking a corpus-based approach, the present article, in addition to those by Basthomi, Wijayanti, Yannuar, and Widiati (2015a), Basthomi, Yannuar, Widiati, and Martiningtyas (2015b) and Basthomi, Yannuar, Hidayati, and Wijayanti (2017), aims to address this issue by comparing academic texts from corpora of Indonesian EFL learners, namely C-SMILE and CINTA, with the Corpus of Contemporary American English (COCA). Thanks to the accessibility of these EFL learner corpora, we are able to keep track of the current condition and trend of advanced EFL students' academic writings. COCA serves as the benchmark against which the academic texts produced by 
the Indonesian learners and the advanced Indonesian EFL students are assessed. The texts produced by the Indonesian learners are incorporated into CINTA (Corpus of Indonesian Texts in Academia) and those produced by Indonesian learners of English are incorporated into C-SMILE-Corpus of State University of Malang Indonesian Learners' English.

We decided to take a corpus-based approach because a contrastive corpus study provides answers to questions about what different groups of language users actually do in their writing (Hyland, 2002a). Hyland (ibid) argues that the study of parallel corpora makes it possible to obtain information on how EFL students perceive academic conventions and how they seek to accommodate their own cultural practices. Moreover, given the increasing demand for academics in all disciplines to publish in English internationally, studies that concentrate on the comparison of rhetorical styles and features between academic texts produced by native speakers and non-native speakers of English are highly relevant because they can reveal which linguistic features merit paying closer attention to Murillo (2012). Such information is important to non-native speakers of English who pursue international recognition through publication, because they inevitably need to adopt a standard of academic writing that is shaped by either academic or cultural conventions (Kafes, 2012). Hyland (1995) also emphasizes the importance of awareness of international writing conventions, which, we believe, have been heavily influenced by English linguistic-cultural norms, as put forth by Hyland:

The need to carry out research and publish results in English language journals presents nonnative speakers with serious problems for they have to work with an unfamiliar cultural and linguistic environment. The research article is the key genre in academic disciplines and a nonnative speaker who wishes to function in the international research world must be familiar with its conventions.

Hyland (1995).

As such, this comparative work was motivated by educational concerns, and is likely to be of use to those to whom English is foreign.

\section{Method}

As noted earlier, this study takes a contrastive corpus-based approach, dealing with written texts (Yusuf, 2009) with a view to educational applications (Al-Sulaiti \& Atwell, 2006). As a corpus project, the study combines both qualitative and quantitative approaches (Biber, Conrad, \& Reppen, 1998). Indeed, as Baker (2006) argues, "unlike purely qualitative approaches to research, corpus linguistics utilizes bodies of electronically encoded text, implementing a more quantitative methodology."

In this project, we have first applied the quantitative technique of obtaining statistical data in the form of the frequency of directives found in the corpora. After deriving the numerical data in the form of raw frequencies, a qualitative approach is used to interpretively explore the issues emerging from the findings. The interpretive discussion, therefore, relies on evidential bases. One reason for choosing a corpus-based design for the study is because reliable theoretical conclusions can be drawn from real language data manifested in a large quantity of material (Feng, 2006). As previously indicated, Hyland's (2002b) categories and lists of directives are referred to in carrying out the analysis of the corpora. Sixty two (62) imperatives, 11 "it is + Adjective + to" - clauses, and 7 modals of obligation were searched in the two corpora.

It would have been problematic to search for each instance of the modals of obligation in such large corpora. The modal must alone, for example, can result in a huge number of search results, some of which are not used to instruct the reader. To ensure that all iterations of must are used by the writer to communicate a suggestion to the reader, and are not included in quotations or examples, would require a great deal of time and meticulous reading as we would need to check one by one. As a solution for this, the search terms were specified by combining the obligation modals suggested by Hyland (2002b) with the reader pronouns defined by Kim and Thompson (2010). So, instead of typing must in the search box, we type you must, one must, we must, and so on. In this way, we can save time and still acquire exact and specific data. In the case of imperatives, we searched for imperatives that (1) occur at the beginning of a sentence, (2) occur after a comma, or (3) occur inside a bracket. This decision was in keeping with the nature of the imperative. After the frequencies of these words and clauses were acquired, we ranked them from most-used to least-used and calculated the percentage of each frequency. The ranked data were then examined, contrasted, and analyzed in keeping with Hyland's (2002b) category of directives, based on their functions in academic texts as documented in the chosen corpora: C-SMILE, CINTA, and COCA.

\subsection{C-SMILE: Corpus of State University of Malang Indonesian Learners' English}

The first source of data is the Corpus of State University of Malang Indonesian Learners English (C-SMILE), which is a collection of 124 undergraduate theses submitted in the years of 2011, 2012, and 2013 to the Department of English, Faculty of Letters, State University of Malang, comprising around 1.6 million words in total. This advanced Indonesian EFL learner corpus comprises academic written texts taken from three specific areas, namely, English Language Teaching, English Literature, and English Linguistics. In this study, C-SMILE mainly serves as a sample of a small corpus to be compared with the larger corpus, COCA. The academic texts, in the form of undergraduate theses, are submitted by undergraduates as a partial fulfillment for the degree of Sarjana (equivalent to 4-year Bachelor of Arts) at the end of their studies.

\subsection{CINTA: Corpus of Indonesian Texts in Academia}

The second source of data for comparison is the Corpus of Indonesian Texts in Academia (CINTA), which is a collection of academic texts gathered from the Indonesian department's undergraduate theses and research articles. The texts are written by students from three departments, namely, Indonesian, Language and Literature Education, and Indonesian Language and Literature. This corpus contains academic texts which were submitted from 2011 to 2017 and comprises nearly 2.8 million words in total. 


\subsection{COCA: Corpus of Contemporary American English}

The third source of data is COCA (Corpus of Contemporary American English) which contains more than 450 million words of American English from the years 1990 to 2012, with around 20 million words being continuously added to the corpus every year (Davies, 2009). This large corpus and its online concordance tool, which were developed by Mark Davies of Brigham Young University, can be accessed online at http://corpus.byu.edu/coca. Consisting of the contents of nearly 100 different peer-reviewed journals, the academic section covers nine genres: education, history, social science, political science, humanities, philosophy, science and technology, medicine, and miscellaneous science. To ensure a balanced comparison in terms of genre, we only made use of the corpus data from research articles in the humanities genre. COCA was chosen as the source of data for this article because of its accessibility and ease of use. Liu (2010) who also used COCA as a data source, praises this corpus for its comprehensiveness, contemporariness, variety of useful user-friendly search functions, and easy access.

\subsection{Analysis}

To obtain the data from C-SMILE and CINTA, we used AntConc 3.2.4., a concordance tool developed by Laurence Anthony of Waseda University, Japan, available for free at http://www.antlab.sci.waseda.ac.jp. We used AntConc 3.2.4., to obtain the frequencies of imperatives, reader pronouns followed by necessity modals, and predicative adjectives in C-SMILE and CINTA. They were then manually ranked from the most prevalent to the least frequent. Similar stages also applied to data collection from COCA. COCA, however, requires no separate concordance tool to utilize its large amount of data. After the frequencies of each occurrence of directives in CSMILE and CINTA were ranked, they were compared with the frequencies of directive occurrences in COCA. The similarities and/or differences observed between the two corpora were then analyzed with reference to the form as well as the function of the directives.

We chose to use AntConc 3.2.4. because it does not need to be installed locally, and more importantly, it allows users to perform different tasks, such as finding frequencies, as well as creating concordances and word lists without any requirements. This program is recommended by Wiechmann and Fuhs (2006) for use by any corpus linguists who deal with multiple files. AntConc 3.2.4 was not used to analyze the corpus data from COCA, because this American corpus is available online and comes equipped with its own concordance tool that can quickly search, limit, and compare frequencies across different sections of the corpus. COCA only requires a sign up to access the whole of its data and all features available in the corpus.

\section{Findings}

The general findings from the corpora suggest that the preferred way to engage readers is by using imperatives, reader pronouns + necessity modals, and "it is + Adjective + to"-clauses, respectively.

\section{Frequency of directives in C-SMILE, CINTA, and COCA}

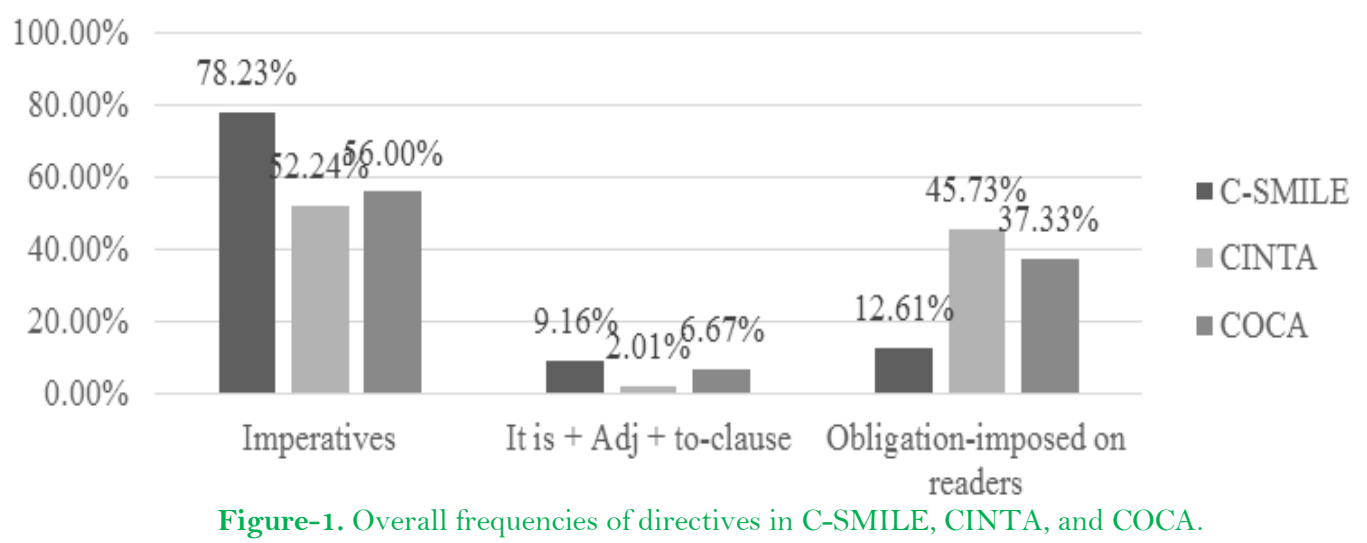

Figure 1 displays the similarity between C-SMILE, CINTA, and COCA data in terms of their frequency of directives. It shows that the frequency of imperatives ranks highest, followed by the frequency of obligationimposed on readers, and finally the frequency of "it is + Adjective + to"-clauses ranks third in the corpora. In CSMILE, fully $78.23 \%$ of directives are by means of imperatives, with only $12.61 \%$ using obligation-imposed-onreaders, and $9.16 \%$ the to-clause. These numbers testify to the heavy use of imperatives in C-SMILE, which then creates a significant gap among the use of three directives. Similarly, imperatives also have the highest frequency in CINTA with $52.24 \%$ in total. The second-most widely used directives in the corpus are of the type obligationimposed-on-readers, which account for $45.73 \%$ of the objectives in the corpus.

In contrast, the gap between the three types of directives in COCA is smaller than that seen in C-SMILE. Imperatives in COCA have the highest frequency of occurrence with $56 \%$. The next is the obligation-imposed-onreaders with $37.33 \%$ of all occurrences and finally the to-cause with only $6.67 \%$. The difference between the frequency of imperatives and obligation-imposed-on-readers in C-SMILE is around 65\%, whereas in COCA this difference is much smaller, only around $19 \%$.

The data displayed in Figure 1 also supports Hyland's (2002b) findings. Based on an analysis of the use of directives in different genres, namely, textbooks, research articles, and student reports, he found that directives in research articles are mostly expressed through the use of imperatives, with 12.6 occurrences per 10,000 words, modals (5.6 occurrences), and "adjective + to"-clauses (0.9 occurrences).

\subsection{The Most Prevalent Directives in the Corpora: Imperatives}

The frequency of imperatives in the two corpora bears further elaboration. There are sixty-two selected English words signaling imperatives that were searched in C-SMILE and COCA. Translations of these English 
words were also searched in CINTA. Table 1 presents the five most frequently used imperatives in C-SMILE and COCA, as well as the four imperatives that are used in CINTA.

Table-1. Five most prevalent imperatives in C-SMILE, CINTA, and COCA

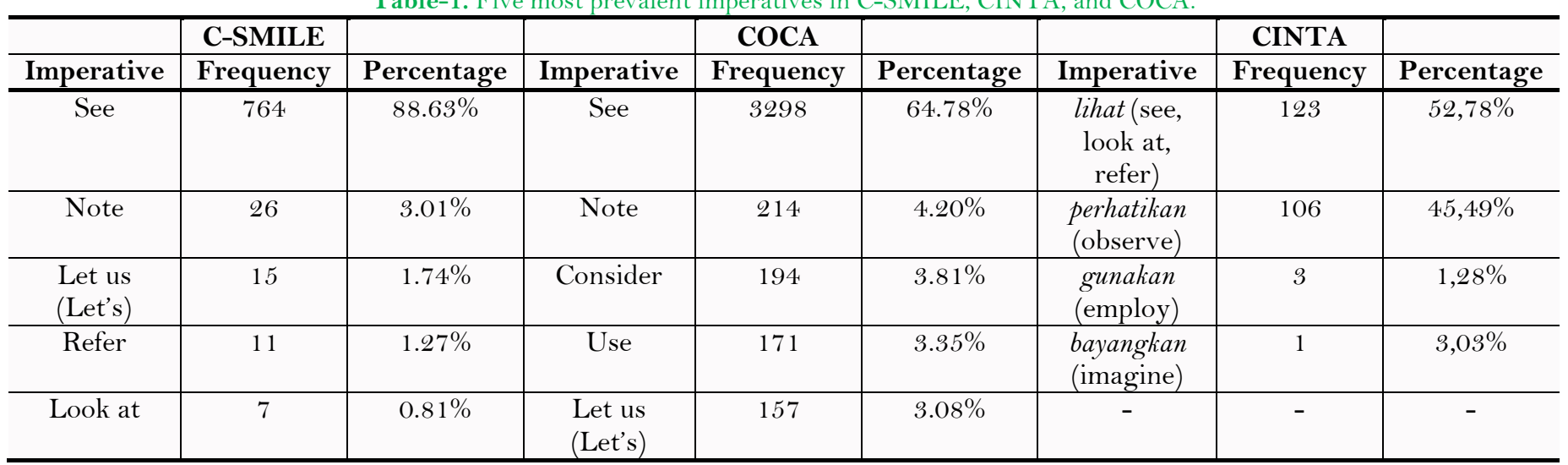

Table 1 shows that see and note are the two most prevalent imperatives in C-SMILE and COCA. Similarly, lihat, which has an equal meaning to see, look at, and refer to, is also frequently used in the Indonesian corpus. In CSMILE, see has the highest frequency with 764 mentions. In the second place is note, used 26 times, almost 30 times less frequently than the first-place imperative see. Let us and Let's appear 15 times in C-SMILE, followed by refer with 11 counts, and look at with only 7. In CINTA, lihat appears 123 times and perhatikan, which means observe, occurs 106 times. In COCA, the imperative see is around 15 times more frequent than note. The cognitive directive consider ranks as the third most prevalent imperative in COCA with 194 instances. Use and let us or let's come next with 171 and 157 respectively.

Interestingly, what we find in C-SMILE, CINTA, and COCA supports what Swales et al. discovered sixteen years ago (Swales et al., 1998). Swales et al. (1998) studied imperatives in research articles from ten different disciplines and ascertained that see, consider, and note were the three most frequent imperatives. This similarity shows us that there have not been many changes in the use of imperatives in academic writing during the last sixteen years. The tendency to employ the textual imperative see is still dominant in academic discourse. This can be explained by the fact that see is the simplest and most efficient way to instruct readers to refer to particular part, page, or source. Some scholarly journals provide very limited space for academic writers to present their work and, consequently, writers are not able to include and write everything. See is therefore used as a quick shortcut to overcome this problem of space, as it guides the reader to find the detailed information on their own.

\subsection{Patterns and Functions of See: See What, Where, and Why?}

According to Hyland (2002b) 'directives allow academic writers to guide readers to some textual acts, referring them to another part of the text or to another text.' The presence of this function of directives has been demonstrated in the C-SMILE, CINTA, and COCA corpora, through the heavy use of textual imperatives see. Not only that, in Excerpt 1, see is also used to suggest that readers examine the cited resources. In other words, see functions not only as an instruction, but also as a suggestion. This can be interpreted as a writer's strategy to make their arguments stronger. Take a look at the samples below and examine the various syntactic patterns of see that occur in the three corpora.

Excerpt 1

(1) ... were given during the need analysis (see Appendix 1, 2), and the try-out (see Appendix). During the need analysis, the questionnaires were given to... (C-SMILE).

(2) ... students' reading skills and increase their vocabulary repertoire as well. (See Appendix for the interview recap with the English teacher). Besides, the... (C-SMILE).

(3) Berdasarkan catatan ahli, ukuran huruf tidak sesuai dengan peserta didik (lihat lampiran IPAPBA 2) (CINTA)

(4) ...oricha-mother and -father, crisscrossed over the chest for the presentacion al tambor. See Matory 1986 and 1991 for brilliant discussions of the role of bodies and vessels as... (COCA).

C-SMILE and COCA exhibit two major syntactic patterns of see. The first pattern, which is the only pattern of see in displayed CINTA, is See + NP as in (1). The noun phrase (NP) might refer to another part of the text such as an appendix, or can also refer to a citation, table, or figure. The second pattern is See $+\mathrm{NP}_{1}+$ for $+\mathrm{NP}_{2}$ as in (2) and (4). This pattern, while found in C-SMILE and COCA, is not in evidence in CINTA. See in (2) is employed not only to instruct readers to study the appendix, but is also used by the writer to provide additional information about the contents of the appendix - to inform that it contains the summary of an interview with the English teacher. This function of see is what (Swales et al., 1998) refer to as a 'metadiscoursal function,' in that it guides readers to tables, figures, other sections of the text, and other outside sources. See in (4) is quite similar to see in (2), but distinct in that see in (4) conveys the writer's attitude toward the proposition. Here, the writer explicitly projects an evaluation of the outside text they refer to through the use of adjectives modifying the mentioned references, such as good, critical, and appealing. Mostly in COCA that these hidden writers' attitudes behind the imperative see are found; they are scarcely found in C-SMILE. Below are some other samples of see $+\mathrm{NP}_{1}+$ for + $\mathrm{NP}_{2}$ carrying the writer's opinions and judgments.

Excerpt 2

(1) ... presents a dilemma. The dilemma, highlighted in the literature of curriculum reform (see, for example, the insightful case studies of science education by David Cohen and ... (COCA).

(2) See Scott, 55-62, for a good summary of these opinions. (COCA).

(3) See the critical letter by G. Wind, "Once More, Michelangelo and Nicodemism... (COCA). 
(4) See also Jos Andrs Rivas' interesting article. (COCA)

Surprisingly, the use of see to convey the writer's attitude or opinion on the referred object is not found in the C-SMILE and CINTA corpora. This is probably because the undergraduate students use see in a very limited way, referring only to, to borrow Hyland's (2002b) term, 'internal references' such as appendices, tables, and figures. Hence, they do not feel the urge to evaluate their own references. Excerpt 3 provides examples of this more limited use.

\section{Excerpt 3}

(1) See Appendix 3 for details (C-SMILE).

(2) See Appendix 3 for the complete analysis (C-SMILE).

(3) See the appendix for the result (C-SMILE).

(4) See appendix for the brief result (C-SMILE).

(5) Lihat contoh a. ii dan a. iii (CINTA).

\section{Discussion}

The statistical data proving the absence of see when used to refer to an external source in the Indonesian corpora warrant the question as to why the writers of undergraduate theses do not instruct their readers to refer to external works. This statistical data also highlights a difference in the usage of see between C-SMILE, CINTA, and COCA. See is indeed commonly used in the American corpus to refer to internal resources, but on a large number of occasions see is used to refer to external sources as well. This difference is emphasized by the fact that in COCA there are some occurrences of see that refer to external sources while at the same time also carry a little piece of information about the contents of the referred material and the writer's evaluation of or attitude toward the material to which they refer.

Informing the readers of the contents of the referred material can, in our opinion, help writers build a credible academic persona, for it proves that the writer has access to relevant source material, has read it all and critically evaluated it, and hence is able to tell the reader exactly and precisely what information a particular source covers. Understanding the contents of certain referred material is necessary for both writer and reader; for the writer, it increases the possibility that the reader will follow their instructions after being provided with precise information about the material. For the reader, this information can help them to judge whether the material is worth reading or not.

In short, to earn reader's trust, a writer should provide answers to the typical questions the readers may have when confronted with the imperative see: what to see, where to find the information, and what benefit there is to following the writer's instruction. The answers to these questions would most typically be formulized in the pattern “See A + year + exact page + for + NP," as demonstrated in Excerpt 4.

\section{Excerpt 4}

(1) See Reff, 1987, 217-220, for a discussion of physiognomic theories relevant to the.... (COCA).

(2) See Armstrong, 1991, 73-100, for the relation of Degas's work to earlier... (COCA).

(3) For criticism of the new exhibition policies, see M. Chapin.... (COCA).

(4) ... as translated from the Yoruba, a place for the receiving of spiritual power (see Brown 1989: 272, fn. 30 for a developed etymology). (COCA).

(5) See the January MENC Soundpost for broadcast stations and times. (COCA).

In examples (1), (2), and (4), the writers go so far as to provide the precise page where the information is presented in the referred material. This information is helpful for readers because it minimizes their responsibility to search for the information on their own.

By providing information, however briefly, about the material they refer to, the writers are actually offering reasons for readers to follow their instructions. If number (3), for instance, were paraphrased into a more casual utterance in spoken interaction, the result would be the writer telling the readers, "I suggest you look at M. Chapin's work, because it talks about criticism of the new exhibition policies," and number (5) might read, "If you need more information about broadcast stations and times, I recommend the January MENC Soundpost because it provides that particular information." These examples demonstrate that in order to influence the reader to follow the writer's textual instructions, writers would do well to provide strong reasons for their commands.

As noted earlier, there are some occurrences of see in COCA which, while referring to external sources, also convey the writer's evaluation of or attitude toward the material they refer to. This function of see is absent from CSMILE and CINTA. In the American corpus, writers sometimes interpolate their judgment about the referred material within the syntactic pattern of "see $+\mathrm{NP}$ " or "see $+\mathrm{NP}_{1}+$ for $+\mathrm{NP}_{2}$ ", by using adjectives (such as brilliant, cogent, critical, engaging, interesting, and good) to modify the mentioned references. Below are some samples taken from the native speaker corpus (see Excerpt 5).

\section{Excerpt 5}

1. See Matory 1986 and 1991 for brilliant discussions of the role of bodies and vessel as... (COCA).

2. See the brief but cogent article by M. Warnke, "Nah und Fern zum Bild... (COCA).

3. See the critical letter by G. Wind, "Once more, Michelangelo and Nicodemism, ... (COCA).

4. See Mark D. Johnston's engaging study of Alemn's "problem with spelling” as... (COCA).

5. See also Jos Andrs Rivas' interesting article. (COCA).

6. See Scott, 55-62, for a good summary of these opinions. (COCA).

The examples above speak to the writers' capability of making judgments about the works they instruct their audience to read. The ability to 'give a judgment' on some academic works can, in our opinion, only be achieved by 
carefully and critically reading the work in question. Therefore, by projecting their attitudes toward the referred material, writers implicitly tell their audience that they have done their homework as a writer, have studied the material and finally have concluded that they are worth recommending to their audience. It hence becomes clear that these adjectives are not attached frivolously. From this explanation, it can be concluded that by projecting their attitude toward an academic article, the writer is building a strong academic persona. Additionally, by appearing to comment on and evaluate the content, the writer is constructing an explicit interaction with their reader (Thompson \& Tribble, 2001).

These findings, however, are not duplicated in C-SMILE and CINTA. The usage of see to refer to an external source is absent in these Indonesian corpora. This raises a concern, because "the ability to make appropriate references to the literature is an essential aspect of successful academic writing and students are expected to demonstrate their knowledge through the display of their reading and integration of that reading into their texts" (Thompson, 2002). It is true that there are several occurrences of see that carry information about the contents of internal references. However, in our opinion, information about internal references is not as critical as that about external ones, for readers are able to predict what the graphics and tables are about, and they simply need to turn to a particular page to see the referred tables, charts, or appendices.

The fact that, according to the statistical data from C-SMILE and CINTA, no writers of undergraduate theses employ see to refer to external references raises a question about the reasons behind the absence of this usage of see in the Indonesian corpora. Basthomi (2012) attempts to answer this question by relating it to the current academic situation in Indonesia. He believes that research activities in Indonesia are not yet mature enough, or in other words, are still nascent (Basthomi, 2012). Consequently, research activities, such as reading previous studies and critically evaluating them, have not yet been well established among most Indonesian academics, especially among undergraduate students. Adnan (2004) has previously documented that Indonesian academics are still confronted with problems regarding a lack of resources. This is probably one of the reasons for the zero occurrences of the use of see to refer to external sources in C-SMILE and CINTA.

In relation to the problem of a lack of resources, such as books, journal articles, and seminar proceedings, a critical question was raised by Basthomi (2009) as to whether "Indonesian academics have the luxury access to the needed materials similar to those enjoyed by their counterpart fellow academics in the better-off countries." From our years of experience in the field of English learning and teaching in Indonesia we have indeed witnessed many undergraduate students who encountered problems in acquiring adequate materials for their papers and projects. In the writing of their final undergraduate theses, for example, most students rely heavily on just three sources: (1) free articles available on Google, (2) the library of the English Self-Access Center (ESAC) within our English Department, and (3) the library of the State University of Malang.

The full article on directives by Swales et al. (1998) that we use as one of the main sources for the present article, for instance, cannot be found in any of the aforementioned sources. Thankfully, we finally discovered that a website of the University of Michigan could offer us full access to the article by simply entering our e-mail address and the title of the article we would like to have. In just two days they sent us the full paper and we were able to download it. Students from countries with a developed academic culture such as the United States have little trouble accessing materials, in contrast to those studying in countries with a nascent academic life. This difference suggests that "there is still a deep intellectual division in the world that remains to be bridged" (Mahbubani, 2009).

One of the implications of the overuse of the textual imperative see in the Indonesian corpora is the corresponding underuse of cognitive imperatives. Kishore Mahbubani, in the $7^{\text {th }}$ International Conference on Thinking that was held in Singapore in June 1997, raised an earth-shaking question: "Can Asian Think?" Mahbubani (2009) provides three possible answers to this controversial question (each with its own strong arguments): no, yes, and maybe. The fact that the cognitive imperatives such as note, consider, examine, think about, and compare are extremely low in C-SMILE and CINTA might provide a further argument in favor of the 'maybe' answer. It should be noted that cognitive imperatives are those imperatives used by writers to instruct their readers to think, to lead them through a line of reasoning, and to direct them to understand a point in a certain way (Hyland, 2002b). Therefore, the fact that imperatives that demand a thought process from the reader appear only in a very low frequency in the corpora signals that the practice of inviting readers to connect ideas and develop their mental process of understanding has not been successfully established in Indonesian academic culture. Consequently, most of the writers and readers have not yet achieved smart-critical thinking ability. In addition, the fact that imperatives such as consider, analyze, and examine are rarely found in C-SMILE and CINTA suggests that we have not yet reached the "high order of thinking skills" as proposed in Bloom's Taxonomy of Learning Objectives (Bloom \& Krathwohl, 1956).

\section{Conclusion}

One difference noted between the Indonesian corpora, C-SMILE and CINTA, and the American corpus, COCA, is in the material that see is used to refer to. In COCA, there are many instances of see that refer to external references, but in C-SMILE and CINTA this usage of see is unheard of. This suggests that Indonesian undergraduates are still confronted with the problems of a lack of resources and that most Indonesian undergraduates do not have easy access to the reading materials they need. To overcome this problem, adequate reading materials in the form of databases of reputed journals or seminar proceedings should be provided by either universities or English departments. In addition, undergraduate students should be making more active use of the reading materials provided for them and independently keeping up with the latest information on research activities, so that the reading materials provided for them are not wasted.

It is also necessary to explicitly introduce various ways of engaging readers into texts during academic writing classes. By doing this, EFL undergraduate students can be familiarized with the patterns and functions of engagement markers, in particular, imperatives, reader pronouns, and predicative adjective in to-clauses. Most importantly, the importance of directing readers and involving them in arguments should be highlighted. Only in this way will the advanced EFL students be able to improve the quality of their undergraduate theses in terms of gaining readers' trust and pulling them into agreement. 
The implication of the overuse of imperative see in C-SMILE and CINTA is the underuse of other imperatives, including the cognitive imperatives. The low frequency of cognitive imperatives in the Indonesian corpora suggests that the practice of inviting readers to connect, compare, and evaluate ideas, and develop their mental process of understanding has not yet been successfully established in Indonesian academic culture. This also suggests that our undergraduate students have not yet arrived at a high order of thinking skills, as defined by Bloom and Krathwohl (1956). It is thus high time for us, as students and teachers, to be aware of this phenomenon, because "the ability to think critically is a vital necessity for the citizens of the $21^{\text {st }}$ century" (Halpern, 2003).

\section{References}

Adel, A., \& Römer, U. (2012). Research on advanced student writing across disciplines and levels: Introducing the Michigan Corpus of Upper-level Student Papers. International Journal of Corpus Linguistics, 17(1), 3-34.Available at: https://doi.org/10.1075/ijcl.17.1.01ade.

Adnan, Z. (2004). Citing behaviours in Indonesian humanities research articles. ASAA E-Journal of Asian Linguistics E Language Teaching, 6, $1-18$.

Al-Sulaiti, L., \& Atwell, E. S. (2006). The design of a corpus of contemporary Arabic. International Journal of Corpus Linguistics, $11(2)$, 135171.Available at: https://doi.org/10.1075/ijcl.1 1.2.02als.

Alkhathlan, M. (2019). Metadiscourse in academic writing: An investigation of Saudi EFL students' Research articles. Linguistics and Literature Studies, 7(5), 220-225.

Baker, P. (2006). Using corpora in discourse analysis. London: Continuum.

Basthomi, Y. (2009). Examining research spaces in ddoctoral prospectuses. TEFLIN Journal, 20(2), 140-158.

Basthomi, Y. (2012). Ambivalences: Voices of academic discourse gatekeepers. English Language Teaching, 5(7), $17-24$.

Basthomi, Y., Wijayanti, L. T., Yannuar, N., \& Widiati, U. (2015a). Third person point of view in EFL academic writing: Ventriloquizing. Journal of Social Sciences and Humanities, 23(4), 1099-1114.

Basthomi., Y., Yannuar, N., Widiati, U., \& Martiningtyas, R. (2015b). C-Smile, COCA, and BNC: A focus on amplifiers and adjective collocations. 3L: The Southeast Asian Journal of English Language Studies, 21(2), 73 - 87.Available at: https://doi.org/10.17576/312015-2102-06.

Basthomi.., Y., Yannuar, N., Hidayati, M., \& Wijayanti, L. T. (2017). It's expected: Between religiosity and evidentiality. KnE Social Sciences, 1(3), 227-237.

Biber, D., Conrad, S., \& Reppen, R. (1998). Corpus linguistics: Investigating language structure and use. Cambridge: Cambridge University Press.

Bloom, B. D., \& Krathwohl, D. R. (1956). Taxonomy of educational objectives: The classification of educational goals by a committee of college and University Examiners. Handbook 1. Cognitive Domain. New York: Addison Wesley.

Brown, P., \& Levinson, S. (1987). Politeness. Cambridge: Cambridge University Press.

Davies, M. (2009). The $385+$ million word corpus of contemporary American english: Design architecture, and linguistic insights. International Journal of Corpus Linguistics, 14(2), 159-190.Available at: https://doi.org/10.1075/ijcl.14.2.02dav.

Feng, Z. (2006). Evolution and present situation of corpus research in China. International Journal of Corpus Linguistics, 11(2), 173207.Available at: https://doi.org/10.1075/ijcl.11.2.03fen.

Guswenda, N. I. (2013). Hedging in written academic discourse: A corpus based-study. Unpublished Sarjana's Thesis, Universitas Negeri Malang, Malang, Indonesia.

Halpern, D. F. (2003). Thought \& knowledge: An Introduction to critical thinking (4th ed.). New Jersey: Lawrence Erlbaum Associates, Inc.

Hyland, K. (2002b). Directives: Argument and engagement in academic writing. Applied Linguistics 23(2), 215-239.Available at: https://doi.org/10.1093/applin/23.2.215.

Hyland, K. (2008). Persuasion, interaction and the construction of knowledge: Representing self and others in research writing. International Journal of English Studies, 8(2), 1-23.

Hyland, K. (2005). Stance and engagement: A model of interaction in academic discourse. Discourse Studies, 7(2), 173-192.Available at: https://doi.org/10.1177/1461445605050365.

Hyland, K. (2002a). Authority and invisibility: Authorial identity in academic writing. Journal of Pragmatics, 34(8), $1091-1112$.

Hyland, K. (1995). The author in the text: Hedging scientific writing. Hong Kong Papers in Linguistics and Language Teaching, 18, 33-42.

Kafes, H. (2012). Cultural traces on the rhetorical organization of research article abstracts. International Journal on New Trends in Education and Their Implications, 3(3), 207-220.

Khoshsima, H., Talati-Baghsiahi, A., Zare-Behtash, E., \& Safaie-Qalati, M. (2018). Interactional metadiscourse in the writings of Novice vs. Established members of academic communities. Journal of English Language Teaching and Learning, 10(22), 63-86.

Kim, C.-K., \& Thompson, G. (2010). Obligation and reader involvement in English and Korean science popularizations: A corpus-based cross-cultural text analysis. Text $\mathcal{E}^{2}$ Talk, 30(1), 53-73.Available at: https://doi.org/10.1515/text.2010.003.

Liu, D. (2010). Is it a chief, main, major, primary, or principal concern?: A corpus-based behavioral profile study of the near-synonyms. International Journal of Corpus Linguistics, 15(1), 56-87.Available at: https://doi.org/10.1075/ijcl.15.1.03liu.

Mahbubani, K. (2009). Can Asians think? Singapore: Fabulous Printers Pte. Ltd.

Murillo, S. (2012). The use of reformulation markers in Business Management research articles: An intercultural analysis. International Journal of Corpus Linguistics, 17(1), 64-90.Available at: https://doi.org/10.1075/ijcl.17.1.03mur.

Swales, J. M., Ahmad, U. K., Chang, Y.-Y., Chavez, D., Dressen, D. F., \& Seymour, R. (1998). Consider this: The role of imperatives in scholarly writing. Applied Linguistics, 19(1), 97-121.Available at: https://doi.org/10.1093/applin/19.1.97.

Thompson, P., \& Tribble, C. (2001). Looking at citations: Using corpora in English for academic purposes. Language Learning \& Technology, 5(3), 91-105.

Thompson, P. (2002). Manifesting intertextuality in the PhD Thesis. Revista Canaria De Estudios Ingleses, 44, 97-1 14.

Toolan, M. (2007). Trust and text, text as trust. International Journal of Corpus Linguistics, 12(2), 269-188.Available at: https://doi.org/10.1075/ijcl.12.2.10too.

Wiechmann, D., \& Fuhs, S. (2006). Concordancing software. Corpus Linguistics and Linguistic Theory, 2(1), 107-127.Available at: https://doi.org/10.1515/cllt.2006.006.

Wijayanti, L. T. (2013). Author self-references: Authorial voice. Unpublished Sarjana's Thesis, Universitas Negeri Malang, Malang, Indonesia.

Yusuf, Y. Q. (2009). A corpus-based linguistics analysis on written corpus: Colligation of "to" and "for". Journal of Language and Linguistic Studies, 5(2), 104-122.

\section{Appendices}

Appendix-1a. Frequency of Imperative in C-SMILE.

\begin{tabular}{l|c|c}
\hline Resources & Tokens & Percentage \\
\hline Add & 1 & $0.11 \%$ \\
\hline Allow & 0 & $0 \%$ \\
\hline Analyze & 4 & $0.46 \%$ \\
\hline Apply & 0 & $0 \%$ \\
\hline Arrange & 1 & $0.11 \%$ \\
\hline Assess & 0 & $0 \%$ \\
\hline
\end{tabular}




\begin{tabular}{|c|c|c|}
\hline Assume & $\mathrm{O}$ & $0 \%$ \\
\hline Calculate & $\mathrm{O}$ & $0 \%$ \\
\hline Choose & $\mathrm{O}$ & $0 \%$ \\
\hline Classify & 1 & $0.11 \%$ \\
\hline Compare & 2 & $0.23 \%$ \\
\hline Connect & $\mathrm{O}$ & $\mathrm{O} \%$ \\
\hline Consult & 1 & $0.11 \%$ \\
\hline Consider & 3 & $0.34 \%$ \\
\hline Define & $\mathrm{O}$ & $0 \%$ \\
\hline Demonstrate & $\mathrm{O}$ & $0 \%$ \\
\hline Determine & 1 & $0.11 \%$ \\
\hline Do not & 4 & $0.46 \%$ \\
\hline Develop & 3 & $0.34 \%$ \\
\hline Employ & $\mathrm{O}$ & $0 \%$ \\
\hline Ensure & 1 & $0.11 \%$ \\
\hline Estimate & $\mathrm{O}$ & $0 \%$ \\
\hline Evaluate & $\mathrm{O}$ & $\mathrm{O} \%$ \\
\hline Find & 1 & $0.11 \%$ \\
\hline Follow & $\mathrm{O}$ & $0 \%$ \\
\hline Go & 3 & $0.34 \%$ \\
\hline Imagine & 2 & $0.23 \%$ \\
\hline Increase & $\mathrm{O}$ & $0 \%$ \\
\hline Input & $\mathrm{O}$ & $0 \%$ \\
\hline Insert & $\mathrm{O}$ & $0 \%$ \\
\hline Integrate & $\mathrm{O}$ & $0 \%$ \\
\hline Key & $\mathrm{O}$ & $0 \%$ \\
\hline Let $A=B$ & $\mathrm{O}$ & $0 \%$ \\
\hline Let us (Let's) & 15 & $1.74 \%$ \\
\hline Look at & 7 & $0.81 \%$ \\
\hline Mark & $\mathrm{O}$ & $\mathrm{O} \%$ \\
\hline Measure & $\mathrm{O}$ & $0 \%$ \\
\hline Mount & $\mathrm{O}$ & $0 \%$ \\
\hline Note & 26 & $3.01 \%$ \\
\hline Notice & $\mathrm{O}$ & $\mathrm{O} \%$ \\
\hline Observe & 2 & $0.23 \%$ \\
\hline Order & $\mathrm{O}$ & $\mathrm{O} \%$ \\
\hline Pay & $\mathrm{O}$ & $0 \%$ \\
\hline Picture & $\mathrm{O}$ & $0 \%$ \\
\hline Prepare & $\mathrm{O}$ & $0 \%$ \\
\hline Recall & $\mathrm{O}$ & $0 \%$ \\
\hline Recover & $\mathrm{O}$ & $\mathrm{O} \%$ \\
\hline Refer & 11 & $1.27 \%$ \\
\hline Regard & $\mathrm{O}$ & $\mathrm{O} \%$ \\
\hline Remember & $\mathrm{O}$ & $0 \%$ \\
\hline Remove & $\mathrm{O}$ & $\mathrm{O} \%$ \\
\hline See & 764 & $88.63 \%$ \\
\hline Select & 1 & $0.11 \%$ \\
\hline Set & $\mathrm{O}$ & $0 \%$ \\
\hline Show & 2 & $0.23 \%$ \\
\hline Suppose & 5 & $0.58 \%$ \\
\hline State & $\mathrm{O}$ & $0 \%$ \\
\hline Think about & $\mathrm{O}$ & $0 \%$ \\
\hline Think of & $\mathrm{O}$ & $0 \%$ \\
\hline Turn & $\mathrm{O}$ & $\mathrm{O} \%$ \\
\hline Use & 1 & $0.11 \%$ \\
\hline TOTAL & 862 & $99.9 \%$ \\
\hline
\end{tabular}

\begin{tabular}{l|c|c}
\multicolumn{1}{c}{ Appendix-1b. Frequency of $i t$ is + Adjective + to - clause in C-SMILE. } \\
\hline Resources & Tokens & Percentage \\
\hline It is crucial to & 1 & $0.99 \%$ \\
\hline It is essential to & 11 & $10.90 \%$ \\
\hline It is imperative to & 0 & 0 \\
\hline It is important to & 58 & $57.42 \%$ \\
\hline It is indispensable to & 0 & 0 \\
\hline It is necessary to & 30 & $0.70 \%$ \\
\hline It is obligatory to & 0 & 0 \\
\hline It is required to & 0 & $0.99 \%$ \\
\hline It is significant to & 1 & 0 \\
\hline It is vital & 0 & $100 \%$ \\
\hline Total & 101 & 0 \\
\hline
\end{tabular}




\begin{tabular}{|c|c|c|c|}
\hline Reader Pronoun & Necessity modal & Tokens & Percentage \\
\hline \multirow[t]{4}{*}{ You } & You should & $\mathrm{O}$ & $\mathrm{O}$ \\
\hline & You need to & 0 & $\mathrm{O}$ \\
\hline & You have to & 1 & $0.71 \%$ \\
\hline & You must & 2 & $1.43 \%$ \\
\hline \multirow[t]{4}{*}{$\mathrm{We}$} & We should & 32 & $23.02 \%$ \\
\hline & We need to & 31 & $22.30 \%$ \\
\hline & We have to & 20 & $14.38 \%$ \\
\hline & We must & 11 & $7.91 \%$ \\
\hline \multirow[t]{4}{*}{ One } & One should & 5 & $3.59 \%$ \\
\hline & One needs to & $\mathrm{O}$ & $\mathrm{O}$ \\
\hline & One has to & $\mathrm{O}$ & $\mathrm{O}$ \\
\hline & One must & 2 & $1.43 \%$ \\
\hline \multirow[t]{4}{*}{ People } & People should & 8 & $5.75 \%$ \\
\hline & People need to & 3 & $2.15 \%$ \\
\hline & People have to & 1 & $0.71 \%$ \\
\hline & People must & 2 & $1.43 \%$ \\
\hline \multirow[t]{4}{*}{ Readers } & Readers should & 4 & $2.87 \%$ \\
\hline & Readers need to & 1 & $0.71 \%$ \\
\hline & Readers have to & 4 & $2.87 \%$ \\
\hline & Readers must & 1 & $0.71 \%$ \\
\hline \multirow[t]{4}{*}{ Researchers } & Researchers should & 9 & $6.47 \%$ \\
\hline & Researchers need to & 1 & $0.71 \%$ \\
\hline & Researchers have to & 1 & $0.71 \%$ \\
\hline & Researchers must & $\mathrm{O}$ & $\mathrm{O}$ \\
\hline Total & & 139 & $99.86 \%$ \\
\hline
\end{tabular}

\begin{tabular}{|c|c|c|}
\hline Resources & Tokens & Percentage \\
\hline Add & 39 & $0.76 \%$ \\
\hline Allow & 26 & $0.51 \%$ \\
\hline Analyze & 6 & $0.11 \%$ \\
\hline Apply & 4 & $0.07 \%$ \\
\hline Arrange & 7 & $0.13 \%$ \\
\hline Assess & 4 & $0.07 \%$ \\
\hline Assume & 3 & $0.05 \%$ \\
\hline Calculate & 0 & $\mathrm{O} \%$ \\
\hline Choose & 29 & $0.57 \%$ \\
\hline Classify & 1 & $0.02 \%$ \\
\hline Compare & 50 & $0.98 \%$ \\
\hline Connect & 2 & $0.04 \%$ \\
\hline Consult & 11 & $0.21 \%$ \\
\hline Consider & 194 & $3.81 \%$ \\
\hline Define & 7 & $0.13 \%$ \\
\hline Demonstrate & 12 & $0.23 \%$ \\
\hline Determine & 14 & $0.27 \%$ \\
\hline Do not & 60 & $1.17 \%$ \\
\hline Develop & 20 & $0.40 \%$ \\
\hline Employ & $\mathrm{O}$ & $\mathrm{O} \%$ \\
\hline Ensure & 5 & $0.09 \%$ \\
\hline Estimate & 0 & $\mathrm{O} \%$ \\
\hline Evaluate & 2 & 0.04 \\
\hline Find & 60 & $1.17 \%$ \\
\hline Follow & 22 & $0.43 \%$ \\
\hline Go & 37 & $0.72 \%$ \\
\hline Imagine & 63 & $1.23 \%$ \\
\hline Increase & 5 & $0.09 \%$ \\
\hline Input & 3 & $0.05 \%$ \\
\hline Insert & 2 & $0.04 \%$ \\
\hline Integrate & 2 & $0.04 \%$ \\
\hline Key & 23 & $0.45 \%$ \\
\hline Let $\mathrm{A}=\mathrm{B}$ & $\mathrm{O}$ & $\mathrm{O} \%$ \\
\hline Let us (Let's) & 157 & $3.08 \%$ \\
\hline Look at & 31 & $0.60 \%$ \\
\hline Mark & 59 & $1.15 \%$ \\
\hline Measure & 6 & $0.11 \%$ \\
\hline Mount & 3 & $0.05 \%$ \\
\hline Note & 214 & $4.20 \%$ \\
\hline Notice & 36 & $0.70 \%$ \\
\hline Observe & 14 & $0.27 \%$ \\
\hline Order & 9 & $0.17 \%$ \\
\hline Pay & 5 & $0.09 \%$ \\
\hline Picture & 3 & $0.05 \%$ \\
\hline Prepare & 9 & $0.17 \%$ \\
\hline
\end{tabular}




\begin{tabular}{l|c|c}
\hline Recall & 29 & $0.57 \%$ \\
\hline Recover & 1 & $0.02 \%$ \\
\hline Refer & 3 & $0.05 \%$ \\
\hline Regard & 3 & $0.05 \%$ \\
\hline Remember & 94 & $1.84 \%$ \\
\hline Remove & 3 & $0.05 \%$ \\
\hline See & 3298 & $64.78 \%$ \\
\hline Select & 17 & $0.33 \%$ \\
\hline Set & 50 & $0.98 \%$ \\
\hline Show & 33 & $0.64 \%$ \\
\hline Suppose & 20 & $0.39 \%$ \\
\hline State & 46 & $0.90 \%$ \\
\hline Think about & 17 & $0.33 \%$ \\
\hline Turn & 37 & $0.72 \%$ \\
\hline Use & 10 & $0.19 \%$ \\
\hline Total & 171 & $3.35 \%$ \\
\hline
\end{tabular}

Appendix-2b. Frequency of it is + Adjective + to - clause in COCA

\begin{tabular}{l|c|c}
\hline Resources & Tokens & Percentage \\
\hline It is crucial to & 25 & $4.11 \%$ \\
\hline It is essential to & 40 & $6.58 \%$ \\
\hline It is imperative to & 11 & $1.81 \%$ \\
\hline It is important to & 377 & $62.10 \%$ \\
\hline It is indispensable to & 0 & 0 \\
\hline It is necessary to & 130 & $21.4 \%$ \\
\hline It is obligatory to & 0 & 0 \\
\hline It is required to & 0 & 0 \\
\hline It is significant to & 4 & $0.65 \%$ \\
\hline It is vital & 20 & $3.29 \%$ \\
\hline TOTAL & $\mathbf{6 0 7}$ & $\mathbf{9 9 . 9 4 \%}$ \\
\hline
\end{tabular}

Appendix-2c. Frequency of obligation-imposed on readers through the use of reader pronouns and necessity modals in COCA.

\begin{tabular}{|c|c|c|c|}
\hline Reader Pronoun & Necessity modal & Tokens & Percentage \\
\hline \multirow[t]{4}{*}{ You } & You should & 232 & $6.83 \%$ \\
\hline & You need to & 121 & $3.56 \%$ \\
\hline & You have to & 182 & $5.36 \%$ \\
\hline & You must & 218 & $6.42 \%$ \\
\hline \multirow[t]{4}{*}{$\mathrm{We}$} & We should & 577 & $17.00 \%$ \\
\hline & We need to & 376 & $11.07 \%$ \\
\hline & We have to & 149 & $4.39 \%$ \\
\hline & We must & 902 & $26.57 \%$ \\
\hline \multirow[t]{4}{*}{ One } & One should & 128 & $3.77 \%$ \\
\hline & One needs to & 30 & $0.88 \%$ \\
\hline & One has to & 54 & $1.59 \%$ \\
\hline & One must & 325 & $9.57 \%$ \\
\hline \multirow[t]{4}{*}{ People } & People should & 22 & $0.64 \%$ \\
\hline & People need to & 3 & $0.08 \%$ \\
\hline & People have to & 3 & $0.08 \%$ \\
\hline & People must & 20 & $0.58 \%$ \\
\hline \multirow[t]{4}{*}{ Readers } & Readers should & 13 & $0.38 \%$ \\
\hline & Readers need to & 3 & $0.08 \%$ \\
\hline & Readers have to & 7 & $0.20 \%$ \\
\hline & Readers must & 15 & $0.44 \%$ \\
\hline \multirow[t]{4}{*}{ Researchers } & Researchers should & 5 & $0.14 \%$ \\
\hline & Researchers need to & 3 & $0.08 \%$ \\
\hline & Researchers have to & 1 & $0.02 \%$ \\
\hline & Researchers must & 5 & $0.14 \%$ \\
\hline Total & & 3,394 & $100 \%$ \\
\hline
\end{tabular}

Appendix-3a. Frequency of Imperative in CINTA

\begin{tabular}{l|l|l|c}
\hline No. & Imperative & Translation & Tokens \\
\hline 1 & compare & bandingkan & 0 \\
\hline 2 & connect & hubungkan, kaitkan & 0 \\
\hline 3 & consider & pertimbangkan & 0 \\
\hline 4 & consult & tanyakan & 0 \\
\hline 5 & consider & pertimbangkan & 0 \\
\hline 6 & define & definisikan & 0 \\
\hline 7 & do not & jangan & 0 \\
\hline 8 & develop & kembangkan & 0 \\
\hline 9 & employ & gunakan & 3 \\
\hline 10 & ensure & pastikan & 0 \\
\hline 11 & find & temukan & 0 \\
\hline 12 & follow & ikuti & 0 \\
\hline
\end{tabular}




\begin{tabular}{l|l|l|c}
13 & imagine & bayangkan & 1 \\
\hline 14 & increase & tingkatkan & 0 \\
\hline 15 & insert & masukkan, sertakan & 0 \\
\hline 16 & integrate & gabungkan & 0 \\
\hline 17 & look at, refer, see & lihat & 123 \\
\hline 18 & mark & tandai & 0 \\
\hline 19 & observe & perhatikan & 106 \\
\hline 20 & think & pikirkan & 0 \\
\hline Total & & 233 \\
\hline
\end{tabular}

Appendix-3b. Frequency of it is + Adjective + to - clause in CINTA

\begin{tabular}{l|l|l|l|l}
\hline No. & It is + Adjective + to - phrase & Translation & Tokens \\
\hline 1 & $\begin{array}{l}\text { it is important/ crucial/ imperative, } \\
\text { essential, to... }\end{array}$ & $\begin{array}{l}\text { penting untuk, penting } \\
\text { untuk }\end{array}$ & 9 \\
\hline
\end{tabular}

\begin{tabular}{l|l|c}
\multicolumn{2}{|l}{ Appendix-3c. Frequency of obligation-imposed on readers through the use of reader pronouns and necessity modals in COCA } \\
\hline No. & Reader pronouns + modal & Tokens \\
\hline 1 & Anda sebaiknya (you should) & 2 \\
\hline 2 & Sebaiknya Anda (you should) & 0 \\
\hline 3 & Anda harus (you must) & 0 \\
\hline 4 & Anda perlu (you need to) & 0 \\
\hline 5 & Kita sebaiknya (we should) & 0 \\
\hline 6 & Kita perlu (we need to) & 26 \\
\hline 7 & Kita harus (we must) & 176 \\
\hline & Total & 204 \\
\hline
\end{tabular}

